Bull. Egypt. Soc. Physiol. Sci. 39 (2), 231-251

\author{
Bull. of Egyp. Soc. Physiol. Sci. \\ (Official Journal of Egyptian Society for Physiological Sciences) \\ (pISSN: 1110-0842; eISSN: 2356-9514)
}

\title{
The Role of Erythropoietin, Vitamin C and L-NAME in Carboplatin- Induced Hematological and Renal Dysfunctions
}

\author{
Ahmed A. El-Gendy ${ }^{1}$, Wael M Elsaed ${ }^{2}$ and Abdelnaser Badawy ${ }^{3}$ \\ ${ }^{1}$ Department of Medical Physiology, Faculty of Medicine, Mansoura University, Mansoura, Egypt. \\ ${ }^{2}$ Department of Anatomy \& Embryology, Faculty of Medicine, Mansoura University, Mansoura, Egypt. \\ ${ }^{3}$ Department of Medical Biochemistry, Faculty of Medicine, Mansoura University, Mansoura ,Egypt.
}

Received: May 7. 2019

Accepted: June 11, 2019

Available online: June 18, 2019

\section{Keywords}

- Vitamin C

- L-NAME

- Carboplatin

- Hematology

- Kidney

\begin{abstract}
Carboplatin is a neoplastic agent causing hematotoxicity, erythropoietin (EPO) resistance, increase oxidative stress and pro-inflammatory cytokines. Our study investigated the role of erythropoietin, vitamin C and L-NAME in carboplatin- induced hematological and renal dysfunctions. Seventy rats divided into seven groups; control, Carboplatin (100 mg/kg.), Carboplatin (250 mg/kg), Carboplatin (100 mg/kg.) pretreated by EPO, Carboplatin ( $250 \mathrm{mg} / \mathrm{kg})$ pretreated by EPO, Carboplatin ( $250 \mathrm{mg} / \mathrm{kg}$ ) pretreated by EPO \& Vitamin C and Carboplatin $(250 \mathrm{mg} / \mathrm{kg}$ ) pretreated by EPO \& L-NAME. Hematological, plasma inflammatory cytokines, renal functions, oxidant, antioxidant parameters, serum EPO and vitamin C were measured with histopathology of renal tissue. Carboplatin decreased RBC count, hemoglobin concentration, packed cells volume, platelets count, superoxide dismutase, catalase and glutathione peroxidase, serum erythropoietin and vitamin $\mathrm{C}$ while WBCs count, interleukin 1, interleukin 6, tumor necrosis factor alpha, high-sensitivity C-reactive protein, serum blood urea nitrogen, serum creatinine, malondialdehyde and nitric oxide were increased. Vitamin C and L-NAME improved hematological derangement, EPO resistance, antioxidant parameters and histopathological findings while worsen plasma inflammatory markers, renal functions parameters and oxidative parameters. There was insignificant change in blood indices in all groups. We concluded that carboplatin had a hematological toxicity and oxidant stress effect in addition to increase proinflammatory cytokines and consequent renal insult. The development of EPO resistance was carboplatin - dose dependent . Vitamin C and L-NAME alleviate the hematological toxicity, oxidative stress, EPO resistance and decrease proinflammatory cytokines and in turn recovery of renal structure and functions.
\end{abstract}

Corresponding author: Ahmed A. El-Gendy, Department of Medical Physiology, Faculty of Medicine, Mansoura University, Mansoura, Egypt, PO box 35516, Mansoura, Egypt, e-mail: ahmedabdelhakim1994@ @utlook.sa, 


\section{INTRODUCTION}

The chemotherapeutic agents have many complications such as hematological and immunological derangements as well as renal dysfunctions [1]. Carboplatin is one of platinumcontaining chemotherapeutic drugs and alkylating agents. Administration of carboplatin is associated with dose-related myelosuppression resulting in anemia, thrombocytopenia and renal dysfunctions [2]. Several mechanisms have been postulated to explain the mechanisms underlying the carboplatin -induced toxicities such as production of reactive oxygen species (ROS), nitric oxide (NO) [3] and proinflammatory cytokines e.g. interleukin-1 (IL1), interleukin-6 (IL-6) and tumor necrosis factor- $\alpha$ $(\mathrm{TNF} \alpha)[4]$.

The immunosuppressive action of carboplatin results in excessive production of reactive $\mathrm{O} 2$ species (ROS) formed by myeloid cells was revealed by many studies [5], which cause auto-oxidation of hemoglobin $(\mathrm{Hb})$ and RBCs damage [2]. Also, nitric oxide (NOx), which is a diffusible free radical generated primarily by the action of NOx synthases (NOS) on L-arginine, inhibits the growth, differentiation, and hemoglobinization of erythroid primary cells. Moreover, the bioactivity of nitric oxide synthases (NOS) mRNA decreases during normal erythropoiesis[6]. So the L-NAME (Nitro-Larginine methyl ester), a non-selective inhibitor of nitric oxide synthase, was administered in this study to clarify this effect. Cytokines, which are produced by many types of cells such as macrophages, lymphocytes, and mast cells, endothelial cells, fibroblasts, and various stromal cells and play an important role in modulation of the functions of individual cells under normal and pathological conditions [7]. Pro-inflammatory cytokines, such as IL-1, IL-6 and TNF- $\alpha$ can modulate erythropoiesis and may play a role in pathogenesis of carboplatin -induced anemia [2] via stimulation of apoptotic process in erythropoietic stem cells. Furthermore, the carboplatin- induced elevation in IL-6 levels causes production of high sensitive C-reactive protein (hsCRP) by liver cells a protein, which activates the complement system. Serum hsCRP concentrations can be used to assess the antioxidant concentrations, which have inverse relation to it [9].

Erythropoietin (EPO), the main regulator of RBCs production, is produced mainly by the kidney (renal peritubular fibroblasts) and to less extent the liver, testis, uterus, skeletal muscles, lungs, and brain [10]. Previous studies had revealed that EPO exerts multiple protective effects, including anti-oxidative [11], antiinflammatory [12] and anti-apoptotic effects [13] Interestingly, Leyland-Jones [14] suggested that erythropoietin is commonly used to induce hematopoietic recovery after chemotherapy. In some cases, there is a development of resistance to EPO, which could be attributed to production of certain inflammatory cytokines, primarily macrophage-derived, including IL-1, IL-6 and TNF- $\alpha$. Moreover, studies by Michelle et al. [15] have shown that administration of EPO can either partially or completely correct the chemotherapy induced - anemia in patients with blocked response to EPO. On other hand, previous study demonstrated that carboplatin - induced inflammation causes resistance of the bone marrow to action of erythropoietin (EPO) causing anemia in a dose dependent manner [8]. On the 
other hand, vitamin $\mathrm{C}$ (ascorbic acid) is an important water-soluble nutrient involved in vital functions within cells, including facilitation of iron transport [16] as well as being one of the most important physiological antioxidants acting on host defense mechanisms assuring immune balance [17].

Vitamin C, a potent antioxidant, has both a preventative and therapeutic role in a number of pathologies when administered at much higherthan-recommended dietary allowance levels, including cancer [18]. It was also revealed that vitamin C alleviates inflammatory reactions [19]. Moreover, there is a limited information about the effects of vitamin $\mathrm{C}$ on the production of cytokines. Calder et al. [20] suggested that vitamin C inhibited production of IL-6 and TNF- $\alpha$ in monocytes. Furthermore, Tan et al. [21] reported that vitamin $\mathrm{C}$ alleviated oxidative stress and proinflammatory mediators since, inflammation plays a major role in the development of EPO resistance. So, in the present study, we investigated the role of erythropoietin, vitamin $\mathrm{C}$ and L-NAME in carboplatin- induced hematological and renal dysfunctions.

\section{Materials \& Methods}

\section{Experimental Animals}

Seventy Sprague-Dawley male rats (weighing $180 \pm 30 \mathrm{gm})$ were used in the experiments. Animals were housed (Medical Experimental Research Center (MERC), Faculty of Medicine, Mansoura University ,Egypt ) in separate cages at $24 \pm 5^{\circ} \mathrm{C}$ with relative humidity of 45 - 55\% under 12 hour's light and dark cycle. Rats were maintained on a standard diet and water was freely available for 2 weeks acclimatization period before the test. All experimental animals were handled in accordance with the standard guide of laboratory animal care of the United States National Institutes of Health (NIH, 1978). All animal procedures were performed in accordance with protocols approved by the Institutional Review Board (IRB) of Mansoura faculty of Medicine, Mansoura University, Egypt.

\section{Chemicals}

Carboplatin (paraplatin) was purchased as a sterile, pyrogen-free, $10 \mathrm{mg} / \mathrm{mL}$ aqueous solution from Bristol-Myers Squibb Company Princeton (New Jersey 08543 USA). Epoetin alfa is recombinant human erythropoietin (EPO) was purchased as a prefilled syringe containing 4000 units $/ 0.4 \mathrm{ml}$. Lascorbic acid (vitamin C) was purchased from Unimed Co. Ltd (Asia, Korea). L-NAME was purchased as powered from Sigma Chemicals ( $\mathrm{St}$ Louis, MO, USA).

\section{Experimental design}

Experimental rats were divided into 7 groups as consist of 10 rats in each group as follow;

1. Group I (Control group):: rats were injected normal saline $(0.9 \% \mathrm{NaCl})$ through duration of experiment.

2. Group II (Carboplatin group, $100 \mathrm{mg}$ ): rats received single injection of carboplatin at a dose of $100 \mathrm{mg} / \mathrm{kg}$ i.p.

3. Group III (Carboplatin group, $250 \mathrm{mg}$ ): rats received single injection of carboplatin at a dose of $250 \mathrm{mg} / \mathrm{kg}$ i.p.

Anemia was induced by a single injection of carboplatin at a dose of 100 and $250 \mathrm{mg} / \mathrm{kg}$ dissolved in $0.9 \% \mathrm{NaCl}$, therefore control groups were injected with $0.9 \% \mathrm{NaCl}[22]$. 
4. Group IV (EPO + carboplatin $100 \mathrm{mg}$ ): as group II but rats received EPO (1000 units $/ \mathrm{kg} / \mathrm{day}$ ) one day before and continue EPO at same dose for 7 days later .

5. Group V (EPO + carboplatin $250 \mathrm{mg}$ ): as group III but rats received EPO (1000 units/kg/day) one day before and continue EPO at same dose for 7 days later.

6. Group VI (Vit C + EPO + carboplatin 250 $\mathrm{mg}$ ): as group $\mathrm{V}$ but rats received vitamin $\mathrm{C}$ at doses of $200 \mathrm{mg} / \mathrm{kg} /$ day i.p. one day before administration of carboplatin and continue for 7 days by the same dose [24].

7. Group V (L-NAME+ EPO + carboplatin 250 $\mathrm{mg}$ ): Group VI but rats received L-NAME at dose at $120 \mathrm{mg} / \mathrm{kg} /$ day i.v. in penile vein one day before administration of carboplatin and continue for 7 days by the same dose [25].

\section{Blood samples collection and kidney harvesting}

By the end of experiment, rats were anaesthetized using $\mathrm{Na}^{+}$thiopental $(12 \mathrm{mg} / \mathrm{Kg}$ i.p.). Blood samples were collected from rats via cardiac puncture, and divided into three tubes; in the first one, blood sample was anticoagulated using sodium citrate and used for determination of hematological parameters using a Sysmex-820 cell counter [Sysmex, Kyoto, Japan]. In the second tube, blood sample was collected without anticoagulant and allowed to coagulate at ambient temperature for $30 \mathrm{~min}$. and the serum was separated by centrifugation at $2000 \mathrm{rpm}$ for $10 \mathrm{~min}$ for biochemical analysis of the serum levels of malondialdehyde (MDA) level, superoxide dismutase (SOD), glutathione peroxidase (GSHPx), catalase (CAT), blood urea nitrogen (BUN), creatinine (S.Cr.), nitric oxide (NOx) and high- sensitivity C-reactive protein (hsCRP). The third sample was collected in EDTA containing tubes for obtaining of plasma to assay the concentrations of ascorbate and cytokines. Also, the abdomen of the rat was opened via midline laparotomy and both kidneys were harvested and stored in formalin $10 \%$ till histopathological examination.

\section{Assay of hematological parameters}

Measurement of RBCs, WBCs and platelets counts was done using Sysmex-820 cell counter [Sysmex, Kyoto, Japan]. Hemoglobin concentration $(\mathrm{Hb} \%)$, packed cells volume (PCV), mean corpuscle volume (MCV), mean corpuscle hemoglobin $(\mathrm{MCH})$, and $\mathrm{MCH}$ concentration were determined.

Assay of plasma cytokines (IL-1, IL-6 and TNFalpha)

Plasma was assayed for the proinflammatory cytokines; IL-1, IL-6, and TNF-alpha using commercially available cytokine kits [28] using Roche modular autoanalyser [Roche modular autoanalyser, Tokyo, Japan]. High-sensitivity Creactive protein (hsCRP) concentration in serum were analyzed using a particle-enhanced immuneturbidimetric assay [CRP Ultra WR Reagent kit, Genzyme) according to manufacturer's instructions on an automated analyzer [29].

\section{Assay of markers of oxidative stress in serum}

The levels of serum MDA, SOD, CAT and GSH-Px were measured using a malondialdehyde assay kit (TBA method) ,total superoxide dismutase assay kit (hydroxylamine method), catalase kit (oxido-reductase activity) and glutathione peroxidase assay kit (colorimetric method) respectively according to the manufacturer's instructions [Nanjing Jiancheng Bioengineering Institute, Nanjing, China) [31]. 


\section{Nitric oxide (NOx) measurement}

The concentration of NO was measured by reduced nicotinamide adenine dinucleotide phosphate (NADPH)-dependent nitrate reductase assay in the serum of rats. After serum nitrate was converted to nitrite by NADPH-dependent nitrate reductase, the total concentration of nitrite was determined by spectrophotometry at $540 \mathrm{~nm}$ [32].

\section{Assay of kidney functions parameters}

To monitor and examine the effects of treatment on renal function, blood was collected on day 7 and serum BUN and serum creatinine were measured using a Beckman BUN analyzer II and Sigma creatinine kit 555, respectively [30].

\section{Assay of serum erythropoietin}

Serum erythropoietin was measured by a solidphase enzyme-linked immunosorbent assay according to the manufacturer's instructions (R\&D, Minneapolis, MN) [33].

\section{Assay of plasma vitamin C}

Plasma concentrations of ascorbate were measured by the colorimetric FRASC (Ferric Reducing/Antioxidant and Ascorbic Acid) assay [34].

\section{Histopathological examination of the kidney} tissues

While animals were under anaesthesia, their abdomins were opened, both kindeys removed, washed by saline, sliced into 25 pieces with $1 \mathrm{~mm}$ thickness that run perpendicular to the long axis of the kidney passing from the cortex to the medulla. The slices were processed for staining by hematoxylene and eosin ( $\mathrm{Hx} \& \mathrm{E})$ by the usual techniques and sujected to light microscopic examination photogarphing.

\section{Statistical analysis}

Data were processed and analyzed using the Statistical Package of Social Science version 10.0 (SPSS, version 10.0). The data were expressed as mean \pm standard error of mean (Mean \pm SEM). One-way ANOVA analysis of data was done followed by Tukey's posthoc test. A minimum level of significance is considered if $\mathrm{p}<0.05$.

\section{Results}

\section{Animal survival}

By the end of experiment, five rats died during the experiment. The final numbers were, group $\mathrm{I}=10$, group $\mathrm{II}=9$, group $\mathrm{III}=8$, group $\mathrm{IV}=10$, group $\mathrm{V}=8$, group $\mathrm{VI}=10$ animals and group $\mathrm{VII}=10$.

\section{Hematological parameters}

Table 1 shows the results of hematological parameters. RBCs count, hemoglobin concentration $(\mathrm{Hb})$, packed cells volume $(\mathrm{PCV})$ and platelets were significantly decreased $(\mathrm{P}<0.001) \quad$ while WBCs were significantly increased in Carboplatin group(II) rats (100 $\mathrm{mg} / \mathrm{kg}$ ) as compared to the control group $(\mathrm{P}<0.001)$.On the other hand, there were insignificant change in mean corpuscle volume $(\mathrm{MCV})$, mean corpuscle hemoglobin $(\mathrm{MCH})$ and $\mathrm{MCH}$ concentration (MCHC).Moreover, rats receiving Carboplatin and EPO (group IV) showed significant increase in $\mathrm{RBC}$ count, $\mathrm{Hb}$, PCV , WBCs and platelets as compared to the group II $(\mathrm{P}<0.001)$. . In addition, there were insignificant change in MCV, MCH and MCHC. Also there were significant decrease $(\mathrm{P}<0.001)$ in RBCs count, $\mathrm{Hb}$ concentration, PCV and platelets in carboplatin $(250 \mathrm{mg} / \mathrm{kg})$ group III , while WBCs were significantly increased as compared to the groups 1\&II $(\mathrm{P}<0.001)$. Also there was 
insignificant change in $\mathrm{MCV}, \mathrm{MCH}$ and $\mathrm{MCHC}$.

Furthermore, Group V showed insignificant change in hematological parameters as compared with group III. Wherever, there were significant increase $(\mathrm{P}<0.001)$ in $\mathrm{RBCs}$ count, $\mathrm{Hb}$ concentration, PCV and platelets in groups VI \& VII while insignificant change regarding $\mathrm{MCV}$, $\mathrm{MCH}, \mathrm{MCHC}$ and WBCs.

\section{Inflammatory cytokines}

Table 2 shows the results of plasma inflammatory markers ,Interleukin 1 (IL-1), Interleukin 6 (IL-6), Tumor necrosis factor alpha (TNF- $\alpha)$ and Highsensitivity C-reactive protein (hsCRP) concentration were significantly increased in Carboplatin group(II) rats $(100 \mathrm{mg} / \mathrm{kg})$ as compared to the control group $(\mathrm{P}<0.001)$. On the other hand ,there were significant decrease in these parameters rather than increase in high-sensitivity C-reactive protein (hsCRP) in rats receiving Carboplatin (100mg/kg) and EPO (group IV) as compared to the group II $(\mathrm{P}<0.001)$. Also there were significant increase $(\mathrm{P}<0.001)$ in parameters mentioned before in Carboplatin $(250 \mathrm{mg} / \mathrm{kg})$ group III as compared to the groups $1 \&$ II $(\mathrm{P}<0.001)$. Furthermore, Group V showed insignificant change in all parameters as compared with group III. Wherever, in groups VI there was insignificant change regarding IL-1 but showed significant decrease in other parameters as compared to group V $(\mathrm{P}<0.001)$. Wherever, Group VII showed a significant decrease in all parameters as compared to group V $(\mathrm{P}<0.001)$.

Table 1 Hematological parameters in different studied groups

\begin{tabular}{|c|c|c|c|c|c|c|c|}
\hline $\begin{array}{l}\text { Hematological } \\
\text { Parameters }\end{array}$ & $\begin{array}{l}\text { Group I } \\
(\mathrm{n}=10 \quad)\end{array}$ & $\begin{array}{c}\text { Group II } \\
(\mathbf{n}=9)\end{array}$ & $\begin{array}{c}\text { Group } \\
\text { III(n=8 ) }\end{array}$ & $\begin{array}{c}\text { Group IV } \\
(n=10)\end{array}$ & $\begin{array}{c}\text { Group V } \\
(n=8)\end{array}$ & $\begin{array}{c}\text { Group VI } \\
(\mathbf{n}=10)\end{array}$ & $\begin{array}{c}\text { Group } \\
\text { VII }(n=10)\end{array}$ \\
\hline $\begin{array}{c}\mathrm{RBC} \text { count } \times \\
10^{12} / \mathrm{L}\end{array}$ & $4.4 \pm 0.56$ & $3.9 \pm 0.45^{\mathrm{a}}$ & $2.8 \pm 0.33^{\mathrm{ab}}$ & $4.6 \pm 0.62^{b c}$ & $2.9 \pm 0.53^{\text {abd }}$ & $4.4 \pm 0.68^{\mathrm{bce}}$ & $4.0 \pm 0.83^{\text {cde }}$ \\
\hline $\begin{array}{c}\text { Hemoglobin } \\
\text { concentration } \\
(\mathbf{H b} \%) \text { g/dl) }\end{array}$ & $\begin{array}{c}13.62 \pm \\
0.31\end{array}$ & $11.93 \pm 1.223^{\mathrm{a}}$ & $6.82 \pm 1.24^{\mathrm{ab}}$ & $14.60 \pm 1.04^{\mathrm{bc}}$ & $7.4 \pm 1.34^{\text {abd }}$ & $13.7 \pm 1.27^{\text {bcde }}$ & $12.91 \pm 1.54 \mathrm{~b}^{\mathrm{cde}}$ \\
\hline $\begin{array}{c}\text { Packed cells } \\
\text { volume (PCV)\% }\end{array}$ & $46 \pm 0.02$ & $\begin{array}{c}41.75 \pm \\
0.31^{\mathrm{a}} \\
\end{array}$ & $\begin{array}{l}20.45 \pm \\
3.37^{\mathrm{ab}} \\
\end{array}$ & $45.68 \pm 0.47^{\mathrm{bc}}$ & $29.24 \pm 1.47^{\text {abcd }}$ & $45.56 \pm 1.83^{\text {bce }}$ & $44.32 \pm 1.43^{\text {bce }}$ \\
\hline $\begin{array}{c}\text { Mean corpuscle } \\
\text { volume } \\
(\mathrm{MCV})\left(\mathrm{um}^{3}\right) \\
\end{array}$ & $84.36 \pm 2.65$ & $83.88 \pm 1.58$ & $85.17 \pm 2.73$ & $85.37 \pm 2.52$ & $82.16 \pm 1.55$ & $86.23 \pm 2.40$ & $85.39 \pm 2.74$ \\
\hline $\begin{array}{c}\text { Mean corpuscle } \\
\text { hemoglobin } \\
(\mathrm{MCH}) \\
\text { fmol/cell } \\
\end{array}$ & $0.45 \pm 0.05$ & $0.44 \pm 0.67$ & $0.41 \pm 0.32$ & $0.41 \pm 0.65$ & $0.40 \pm 0.52$ & $0.48 \pm 0.45$ & $0.43 \pm 0.34$ \\
\hline $\begin{array}{c}\text { MCH } \\
\text { concentration } \\
(\mathrm{MCHC})(\mathrm{g} / \mathrm{dL})\end{array}$ & $33.21 \pm 1.30$ & $32.46 \pm 1.43$ & $31.73 \pm 1.42$ & $31.41 \pm 1.05$ & $32.85 \pm 1.46$ & $34.34 \pm 1.54$ & $33.27 \pm 1.95$ \\
\hline $\begin{array}{c}\text { WBCs } \\
\operatorname{count}\left(\mathbf{x 1 0}^{3} /\right. \\
\left.\mathrm{mm}^{3}\right) \\
\end{array}$ & $5.56 \pm 1.37$ & $8.67 \pm 1.40^{\mathrm{a}}$ & $20.71 \pm 2.32^{\mathrm{ab}}$ & $12.34 \pm 0.34^{\mathrm{abc}}$ & $19.63 \pm 3.43^{\mathrm{abd}}$ & $22.72 \pm \underset{\mathrm{d}}{2.59^{\mathrm{abc}}}$ & $23.21 \pm 1.31^{\mathrm{abd}}$ \\
\hline $\begin{array}{c}\text { Platelets count } \\
(\times 1000 / \mu \mathrm{L})\end{array}$ & $\begin{array}{c}150.93 \pm 10 . \\
26\end{array}$ & $110.32 \pm 1.84^{\mathrm{a}}$ & $60.36 \pm 5.38^{\mathrm{ab}}$ & $145.57 \pm 9.36^{\mathrm{bc}}$ & $57.35 \pm 2.48^{\text {abd }}$ & $\underset{\text { abcde }}{210.35 \pm 11.58}$ & $\underset{\text { bcde }}{180.42 \pm 10.47^{\mathrm{a}}}$ \\
\hline
\end{tabular}

The values were expressed as Mean \pm SEM

${ }^{a}$ Significant $(p<0.05)$ compared with control group

${ }^{\mathrm{b}}$ Significant $(\mathrm{p}<0.05)$ compared with group II

${ }^{\mathrm{c}}$ Significant $(\mathrm{p}<0.05)$ compared with groupIII

${ }^{\mathrm{d}}$ Significant $(\mathrm{p}<0.05)$ compared with group IV

e Significant $(\mathrm{p}<0.05)$ compared with group V 
Table 2 Plasma inflammatory markers in different studied groups

\begin{tabular}{|c|c|c|c|c|c|c|c|}
\hline $\begin{array}{c}\text { Plasma } \\
\text { inflammato } \\
\text { ry markers }\end{array}$ & $\begin{array}{l}\text { Group I } \\
(n=10)\end{array}$ & $\begin{array}{c}\text { Group } \\
\text { II }(n=9)\end{array}$ & $\begin{array}{c}\text { Group } \\
\text { III(n=8 })\end{array}$ & $\begin{array}{c}\text { Group IV } \\
(n=10)\end{array}$ & $\begin{array}{c}\text { Group } \\
\text { V(n=8) }\end{array}$ & $\begin{array}{c}\text { Group } \\
\text { VI }(n=10)\end{array}$ & $\begin{array}{c}\text { Group } \\
\text { VII(n=10 ) }\end{array}$ \\
\hline $\begin{array}{c}\text { Interleukin } \\
1 \text { (IL-1) } \\
\text { g IL-6 }\end{array}$ & $\begin{array}{c}18.31 \pm \\
0.52\end{array}$ & $\begin{array}{c}25.90 \pm \\
0.42^{\mathrm{a}}\end{array}$ & $40.32 \pm 1.57^{\mathrm{ab}}$ & $19.06 \pm 0.67^{\mathrm{bc}}$ & $42.32 \pm 2.36^{\mathrm{abd}}$ & $39.36 \pm 1.37^{\mathrm{abd}}$ & $18.37 \pm{ }_{\text {ef }} 1.20^{\text {bcd }}$ \\
\hline $\begin{array}{c}\text { Interleukin } \\
6 \text { (IL-6) } \\
\text { pg.mL }\end{array}$ & $66.62 \pm 2.42$ & $163.73 \pm 1.74$ & $\begin{array}{c}403.38 \pm 20.7 \\
3^{\mathrm{ab}}\end{array}$ & $\underset{b c}{100.32 \pm 1.38^{a}}$ & $\underset{\text { abd }}{398.72 \pm 12.82}$ & $70.52 \pm 8.54^{\text {bcd }}$ & $79.51 \pm \underset{\mathrm{e}}{6.42^{\mathrm{bcd}}}$ \\
\hline $\begin{array}{l}\text { Tumor } \\
\text { necrosis } \\
\text { factor } \\
\text { alpha } \\
\text { (TNF- } \alpha) \\
\text { pg. mL }{ }^{-1}\end{array}$ & $\begin{array}{c}323.63 \pm 25 \\
74\end{array}$ & $\begin{array}{c}432.60 \pm 32.6 \\
4^{\mathrm{a}}\end{array}$ & $\begin{array}{c}681.43 \pm \\
32.24^{\mathrm{ab}}\end{array}$ & $\begin{array}{c}330.27 \pm 26.6 \\
4^{\mathrm{bc}}\end{array}$ & $\underset{\text { abd }}{650.52 \pm 26.51}$ & $\begin{array}{c}350.63 \pm 24.83 \\
\text { bce }\end{array}$ & $\begin{array}{c}358.42 \pm 23.64 \\
\text { bce }\end{array}$ \\
\hline $\begin{array}{c}\text { High- } \\
\text { sensitivity } \\
\text { C-reactive } \\
\text { protein } \\
\text { (hsCRP) } \\
\text { (mg/ml) }\end{array}$ & $0.51 \pm 0.63$ & $1.83 \pm 0.34^{\mathrm{a}}$ & $4.21 \pm 0.71^{\mathrm{ab}}$ & $2.35 \pm 0.11^{\mathrm{abc}}$ & $4.97 \pm 1.55^{\mathrm{abd}}$ & $0.72 \pm 0.32^{\text {bcde }}$ & $0.84 \pm 0.23^{\text {bcde }}$ \\
\hline
\end{tabular}

The values were expressed as Mean \pm SEM

${ }^{a}$ Significant $(\mathrm{p}<0.05)$ compared with control group

${ }^{\mathrm{b}}$ Significant $(\mathrm{p}<0.05)$ compared with group II

${ }^{c}$ Significant $(\mathrm{p}<0.05)$ compared with groupIII

${ }^{\mathrm{d}}$ Significant $(\mathrm{p}<0.05)$ compared with group IV

${ }^{\mathrm{e}}$ Significant $(\mathrm{p}<0.05)$ compared with group V

${ }^{\mathrm{f}}$ Significant $(\mathrm{p}<0.05)$ compared with group VI
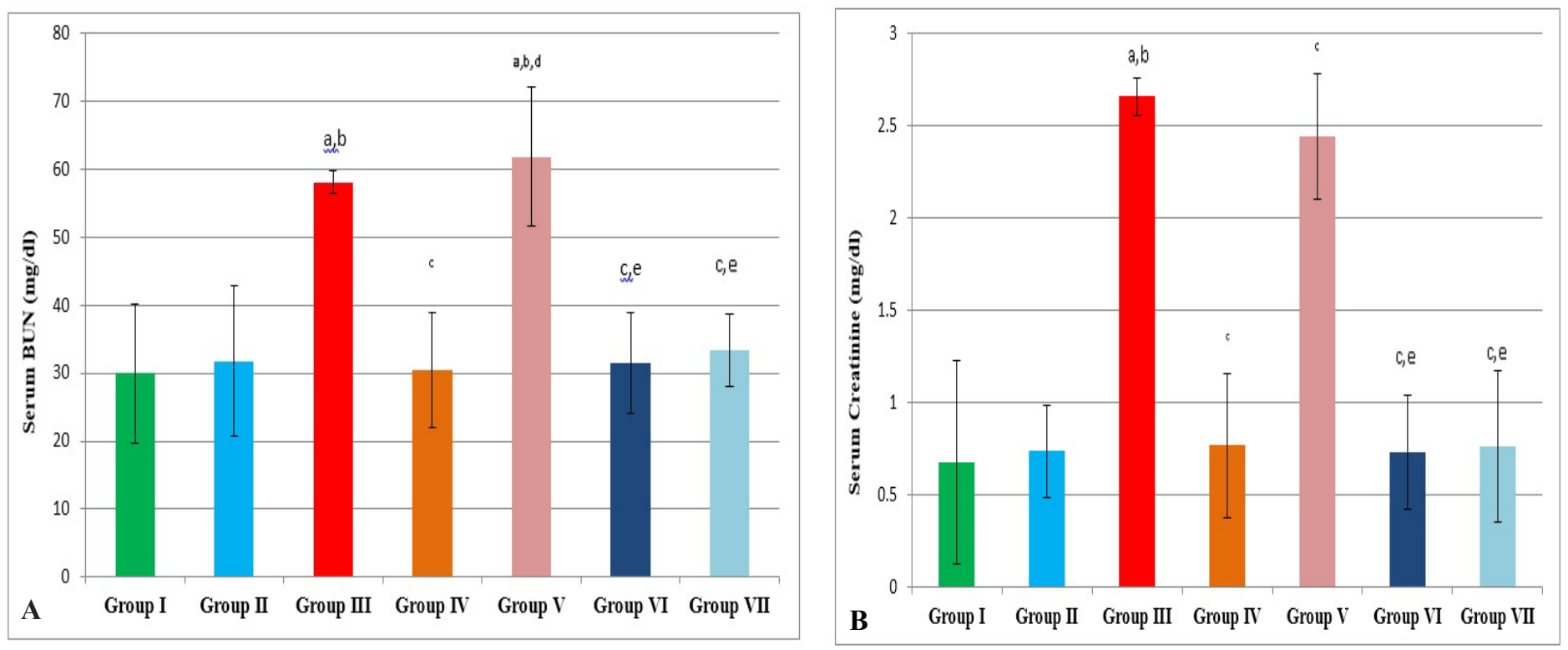

Figure 1 Serum levels of A) blood urea nitrogen and B) creatinine in different studied groups . The values were expressed as Mean \pm SEM, ${ }^{a}$ Significant $(p<0.05)$ compared with control group, ${ }^{b}$ Significant $(p<0.05)$ compared with group II, ${ }^{c}$ Significant $(p<0.05)$ compared with groupIII, ${ }^{d}$ Significant $(p<0.05)$ compared with group IV, ${ }^{e}$ Significant $(p<0.05)$ compared with group $\mathrm{V}$ 


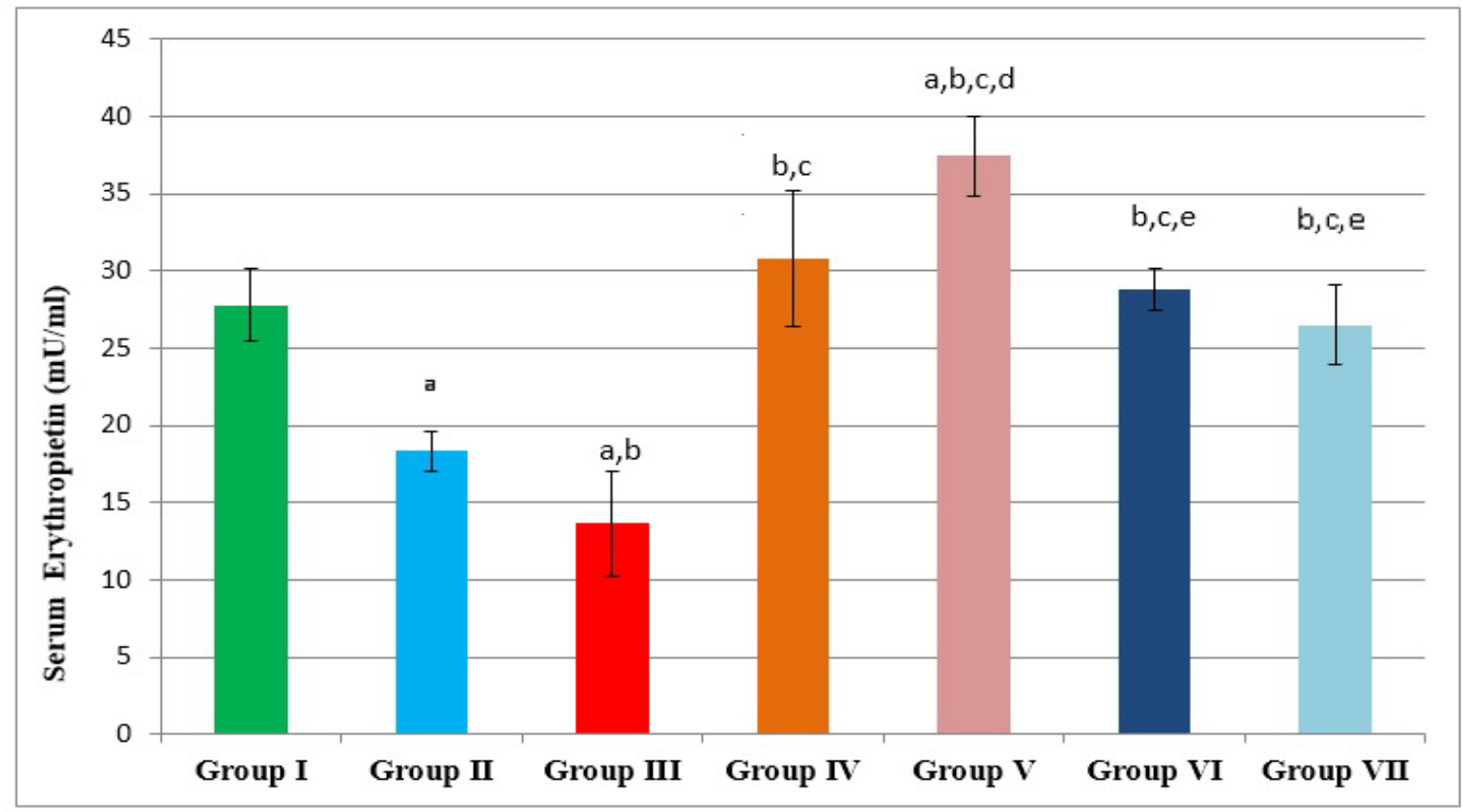

Figure 2 Serum levels of erythropoietin in different studied groups. The values were expressed as Mean \pm SEM. ${ }^{a}$ Significant $(\mathrm{p}<0.05)$ compared with control group, ${ }^{\mathrm{b}}$ Significant $(\mathrm{p}<0.05)$ compared with group II, ${ }^{\mathrm{c}}$ Significant $(\mathrm{p}<0.05)$ compared with groupIII, ${ }^{\mathrm{d}}$ Significant $(\mathrm{p}<0.05)$ compared with group IV,${ }^{\mathrm{e}}$ Significant $(\mathrm{p}<0.05)$ compared with group V

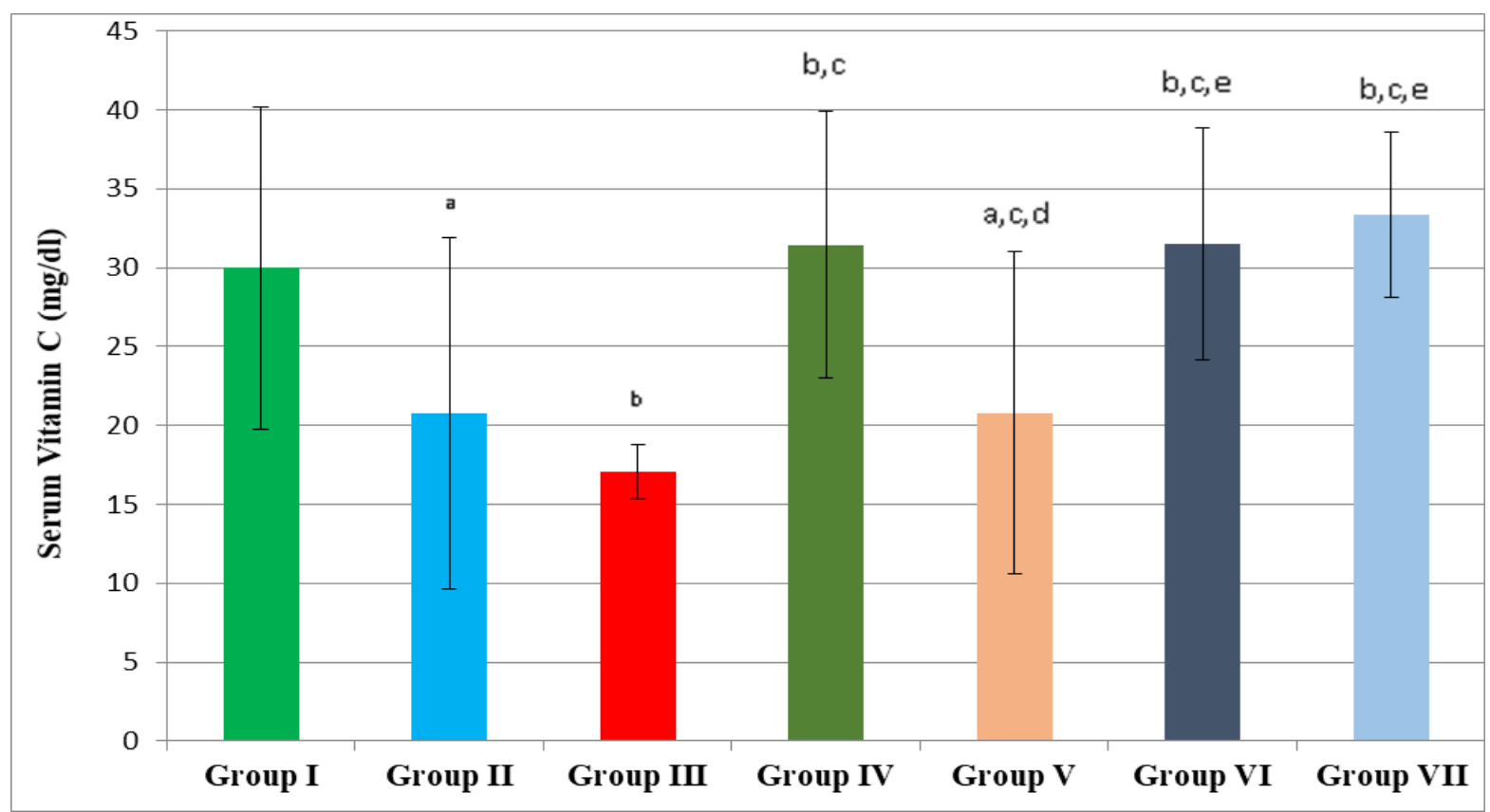

Figure 3 Serum levels of vitamin $C$ in different studied groups. The values were expressed as Mean \pm SEM, ${ }^{\text {a }}$ Significant $(\mathrm{p}<0.05)$ compared with control group, ${ }^{\mathrm{b}}$ Significant $(\mathrm{p}<0.05)$ compared with group II, ${ }^{\mathrm{c}}$ Significant $(\mathrm{p}<0.05)$ compared with groupIII, ${ }^{\mathrm{d}}$ Significant $(\mathrm{p}<0.05)$ compared with group IV, ${ }^{\mathrm{e}}$ Significant $(\mathrm{p}<0.05)$ compared with group V

\section{Kidney functions, markers of oxidative stress and} NOx

Table 3 \& Figures 1A-B, $2 \& 3$ show the effect of EPO and Carboplatin (100 and 250 $\mathrm{mg} / \mathrm{kg}$ ip) treated rats on renal functions parameters , oxidative, antioxidant parameters , nitric oxide (NOx) and levels of serum EPO, vitamin $\mathrm{C}$ in control group. Also they demonstrated the effect of vitamins $\mathrm{C}$ and L-NAME on same parameters in 
Carboplatin-induced EPO resistance. Group II showed insignificant changes regarding renal functions parameters (BUN\& S.Cr.) but significant increase $(\mathrm{P}<0.001)$ in malondialdehyde (MDA) and nitric oxide (NOx). Also, significant decrease $(\mathrm{P}<0.001)$ in superoxide dismutase (SOD), catalase (CAT) and glutathione peroxidase (GSHPx ), in addition, group II showed a significant decrease in serum erythropoietin (EPO) and vitamin $\mathrm{C}$ as compared to group I. Moreover, group IV showed non-significant changes regarding renal functions parameters (BUN \& S.Cr.) and significant decrease $(\mathrm{P}<0.001)$ in MDA and NOx. Also significant increase $(\mathrm{P}<0.001)$ in
SOD, CAT and GSH-Px. In addition, group IV showed a significant increase $(\mathrm{P}<0.001)$ in serum EPO and vitamin $\mathrm{C}$ as compared to group II. On the other hand, group III showed significant increase $(\mathrm{P}<0.001) \quad$ in BUN, S.Cr., MDA, NOx and significant decrease $(\mathrm{P}<0.001)$ in SOD, CAT, GSH-Px, EPO and vitamin $\mathrm{C}$ as compared to groups I \& II. Wherever the levels of BUN, S.Cr., MDA , NO and EPO showed a significant decrease $(\mathrm{P}<0.001)$ in groups VI \& VII and significant increase in SOD, CAT, GSH-Px and vitamin $\mathrm{C}$ as compared to group $\mathrm{V}$.

\section{Kidney morphology}

Table 3 Oxidants, antioxidants and nitric oxide (NOx) levels in different studied groups.

\begin{tabular}{|c|c|c|c|c|c|c|c|}
\hline & $\begin{array}{l}\text { Group I } \\
(\mathrm{n}=10)\end{array}$ & $\begin{array}{l}\text { Group } \\
\text { II }(\mathbf{n}=9)\end{array}$ & $\begin{array}{c}\text { Group } \\
\text { III(n=8 ) }\end{array}$ & $\begin{array}{c}\text { Group IV } \\
(n=10)\end{array}$ & $\begin{array}{c}\text { Group } \\
\text { V(n=8 })\end{array}$ & $\begin{array}{c}\text { Group } \\
\text { VI }(n=10)\end{array}$ & $\begin{array}{c}\text { Group } \\
\text { VII }(n=10)\end{array}$ \\
\hline $\begin{array}{c}\text { Malonicdialdeh } \\
\text { yde (MDA) } \\
\mathrm{nmol} / \mathrm{ml}\end{array}$ & $\begin{array}{c}11.38 \pm 1 \\
01\end{array}$ & $17.85 \pm 1.32^{\mathrm{a}}$ & $\underset{\mathrm{ab}}{26.60 \pm 1.37}$ & $\underset{b c}{10.98 \pm 1.37}$ & $\underset{\text { abd }}{24.73 \pm 1.28}$ & $\begin{array}{c}11.64 \pm 0.63 \\
\text { bce }\end{array}$ & $12.46 \pm \underset{\mathrm{e}}{ \pm 0.33^{\mathrm{bc}}}$ \\
\hline $\begin{array}{l}\text { Superoxide } \\
\text { dismutase } \\
(\mathrm{SOD})(\mathrm{U} / \mathrm{L})\end{array}$ & $\begin{array}{c}266.0 \pm 4 . \\
61\end{array}$ & $94.37 \pm 5.28^{\mathrm{a}}$ & $\underset{\mathrm{ab}}{25.58 \pm 05.16}$ & $\begin{array}{c}230.57 \pm 5.8 \\
6^{\text {bc }}\end{array}$ & $35.52 \pm 4.67^{\mathrm{abc}}$ & $\begin{array}{c}234.11 \pm 4.1 \\
6^{\text {bce }}\end{array}$ & $\underset{\text { bcde }}{229.54 \pm 6.45}$ \\
\hline $\begin{array}{c}\text { Catalase(CAT) } \\
(\mathrm{U} / \mathrm{L})\end{array}$ & $\begin{array}{c}14.37 \pm 2 . \\
42\end{array}$ & $9.43 \pm 1.29^{\mathrm{a}}$ & $2.12 \pm 1.31^{\mathrm{ab}}$ & $\underset{\mathrm{bc}}{12.87 \pm 1.45}$ & $6.14 \pm 1.62^{\mathrm{abcd}}$ & $\underset{\text { cde }}{15.07 \pm 2.31^{b}}$ & $14.51 \pm 1.80^{\mathrm{bc}}$ \\
\hline $\begin{array}{c}\text { Glutathione } \\
\text { Peroxidase } \\
\text { (GSH-Px } \\
\text { ) } \mu \mathrm{mol} / 1\end{array}$ & $\begin{array}{c}95.6 \pm 2.5 \\
2\end{array}$ & $50.63 \pm 2.74^{\mathrm{a}}$ & $31.78 \pm 2.71^{\mathrm{ab}}$ & $92.3 \pm 2.10^{\mathrm{bc}}$ & $37.82 \pm 3.41^{a b c}$ & $\underset{\text { bce }}{93.8 \pm 1.55}$ & $89.53 \pm 2.95^{b c}$ \\
\hline $\begin{array}{c}\text { Nitric oxide } \\
(\mathrm{NOx})(\mu \mathrm{mol} / \mathrm{L})\end{array}$ & $\begin{array}{c}77.1 \pm 31 \\
42\end{array}$ & $\begin{array}{c}130.36 \pm 24 \\
27^{\mathrm{a}}\end{array}$ & $\begin{array}{c}193.43 \pm 23.8 \\
4^{\mathrm{ab}}\end{array}$ & $80.1 \pm \underset{b c}{21.32}$ & $\begin{array}{c}182.61 \pm 20.8 \\
7^{\text {abd }}\end{array}$ & $\underset{\text { abcde }}{34.81 \pm 5.42}$ & $\underset{\text { abcde }}{38.80 \pm 3.37}$ \\
\hline
\end{tabular}

The values were expressed as Mean \pm SEM

${ }^{a}$ Significant $(\mathrm{p}<0.05)$ compared with control group

${ }^{\mathrm{b}}$ Significant $(\mathrm{p}<0.05)$ compared with group II

${ }^{\mathrm{c}}$ Significant $(\mathrm{p}<0.05)$ compared with groupIII

${ }^{\mathrm{d}}$ Significant $(\mathrm{p}<0.05)$ compared with group IV

${ }^{\mathrm{e}}$ Significant $(\mathrm{p}<0.05)$ compared with group $\mathrm{V}$

Figure 4 shows the findings of histopathological examination by LM: Group I (control group) demonstrated the normal structure of the kidney with the renal corpuscles, proximal and distal convoluted tubules (Figure 4. I). The renal cortices of group II showed marked pathological changes in the form of patches of necrosis with widening of the Bowman's spaces and vaccuolation of the cytoplasm of the renal tubules (Figure 4. II). Group III had more extensive pathological changes with patchy necrosis and widening of the Bowman's spaces. Most of the cell lining of the renal tubules appeared distended with 
occlusion of the renal tubular lumen (Figure 4.

III). Group IV had no areas of focal necrosis but

bowmans spaces still showing apparent widening.

The renal tubular cell lining had less marked signs

of degeneration (Figure 4. IV). Group V showed

near normal structure of the glomeruli but the renal

tubules showed widened lumens with vacculation of the cellular lining (Figure 4. V). Group VI had almost normal renal corpuscles but still the renal tubules had wider lumens (Figure 4. VI). Finally group VII had a very close picture of normality in both the renal corpuscles and tubules (Figure 4. VII).
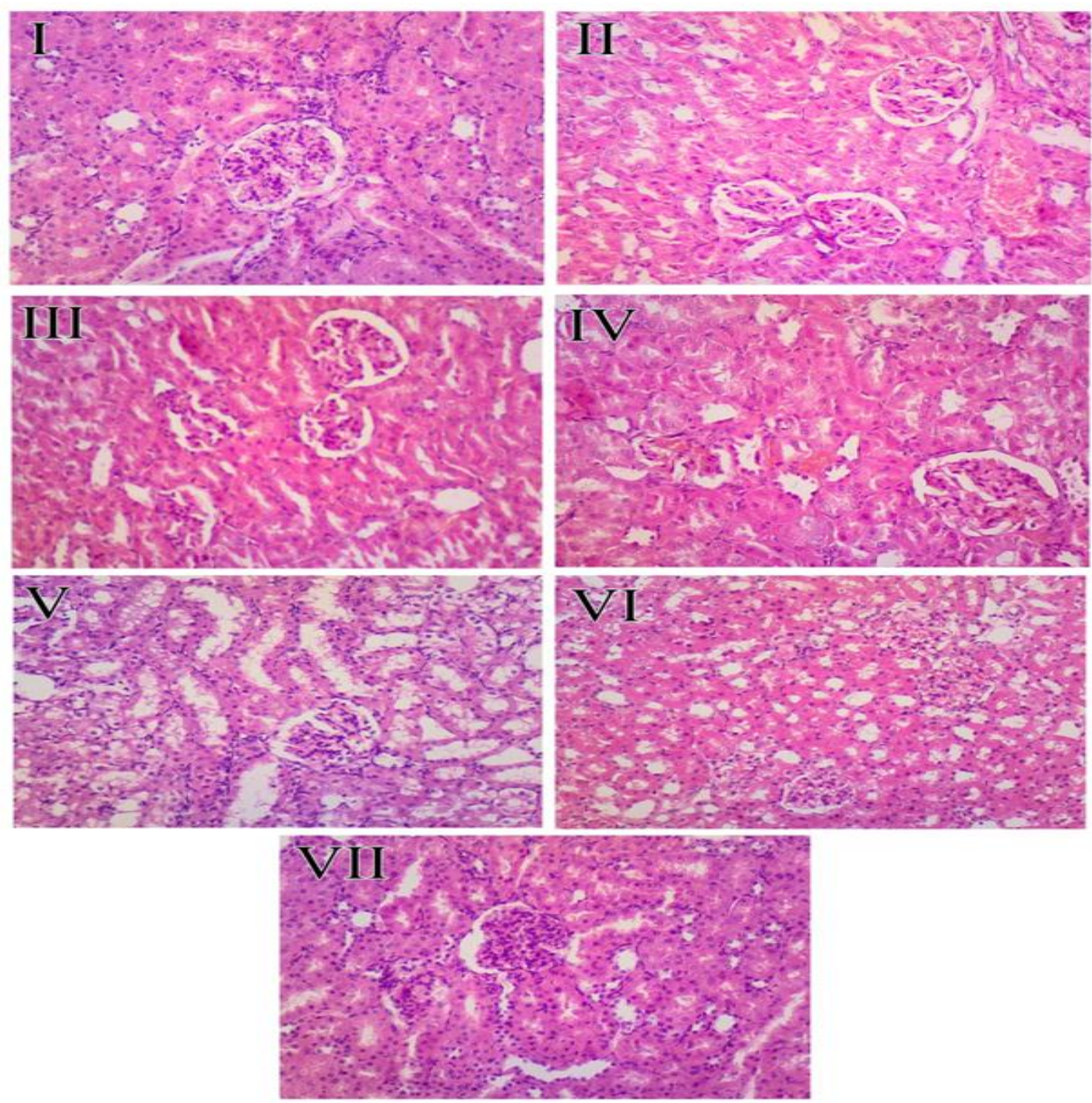

Figure 4 Sections of the kidneys demonstrated that group I (control group) had normal structure of the kidney with the renal corpuscles, proximal and distal convoluted tubules (Fig. 3. I). The renal cortices of group II showed marked pathological changes in the form of patches of necrosis with widening of the Bowman's spaces and vaccuolation of the cytoplasm of the renal tubules (Fig. 3. II). Group III had no areas of focal necrosis but bowmans spaces still showing apparent widening. The renal tubular cell lining had less marked signs of degeneration (Fig.3 .III). Group IV had more extensive pathological changes with patchy necrosis and widening of the Bowman's spaces. Most of the cell lining of the renal tubules appeared distended with occlusion of the renal tubular lumen (Fig.3 .IV). Group V showed near normal structure of the glomeruli but the renal tubules showed widened lumens with vacculation of the cellular lining (Fig.3. V). Group VI had almost normal renal corpuscles but still the renal tubules had wider lumens (Fig.3. VI). Finally group VII had a very close picture of normality in both the renal corpuscles and tubules (Fig.3. VII) (Hx \& E x400). 


\section{Discussion}

The present study revealed that Carboplatin administration leads to increase oxidative biomarkers; MDA and NOx and decreased the activity of antioxidant enzymes, including SOD, CAT and GSH-Px in the serum which affects immune system via increasing the expression of cytokines (IL-1, IL-6, and TNFalpha) by endothelium, macrophages and mast cells [35]. It was also demonstrated that the increase in oxidative stress, free radicals and cytokines are associated with chemotherapy induced hematoxicity and renal injury [36]. This was reported by Dallalio et al. [37] who proved that inflammatory cytokine-mediated anemia of chemotherapy may occur through modulation of oxidative stress.

Furthermore, groups II \& III showed hematological disturbances, 7 days after Carboplatin treatment, manifested by significant alterations in $\mathrm{RBC}, \mathrm{Hb}, \mathrm{PCV}, \mathrm{WBC}$, and platelets. This could be attributed to suppression of hematopoietic tissues, disturbance in erythropoiesis, impaired erythrocyte membrane permeability, immune hemolysis, disturbed iron metabolism and apoptosis of immature hematopoietic cells which are the main causes of anemia and thrombocytopenia [37]. The results in group IV indicated that pretreatment with EPO especially with low dose Carboplatin $(100 \mathrm{mg} / \mathrm{kg})$ can increase $\mathrm{RBC}$ count, $\mathrm{Hb} \%$ \& $\mathrm{PCV}$ and platelets count correcting anemia \& thrombocytopenia [13]. In contrast, the effects of Carboplatin on hematological parameters with high dose $(250 \mathrm{mg} / \mathrm{kg})$ as in group III showed significant decrease in erythrocytes count, $\mathrm{Hb}$, , $\mathrm{PCV}$ and platelets, with a blunted response to EPO administration in high dose of carboplatin was found in group V. From these results we can suppose that hematological toxicity of Carboplatin injection is dose-dependent [39].

Interestingly, occurrence of anemia during Carboplatin therapy should raise suspicion of immune hemolysis as suggested by Levi et al. [40]. Moreover, previous work by Theurl et al. [41] has demonstrated that serum EPO levels are lower in carboplatin treated patients as evidenced in our results in groups II \& III . The data in this study support the view that decrease Epo production in affected kidney contributes to the anemia in Carboplatin group and diminished sensitivity of the Epo response. High levels of proinflammatory cytokine (IL-1, IL-6, and TNF- $\alpha$ ) shown in group III \& V, produced by immune activation of the hematopoietic tissues and $\mathrm{T}$ cells, inhibit EPO production in the kidneys, resulting in appropriately low levels in the blood, as well as directly inhibiting the proliferation and differentiation of erythrocyte progenitor cells in addition to limited availability of iron and antagonizing the antiapoptotic actions of EPO and hence faster the development of anemia[42].Moreover, IL-6 stimulates hepatic production of an acute phase protein, hepcidin, inhibiting absorption of iron in duodenum[43]. Hepcidin, when released by the liver inhibits ferroportin [44]. This is a transmembrane protein found in enterocytes, macrophages and hepatocytes, which is responsible for the transfer of $\mathrm{Fe}^{2+}$ absorbed into the circulation and bone marrow and thus favoring anemia, even in the presence of total body iron stores, i.e., the socalled functional iron deficiency [44]. Moreover, 
this direct negative effect on erythrocyte progenitor cells may be primarily due to inadequate response to the action of EPO (group V) in treatment of chemotherapy induced- anemia and the destruction is also accelerated due to increased clearance by macrophage or marked hemolysis during severe inflammation could also contribute to decreased red blood cells [45]. Many studies showed that erythroid colony formation in response to Epo is impaired in the presence of proinflammatory cytokines without providing molecular mechanisms. In all groups proinflammatory cytokines affect Epo either by inhibition of its production by kidney or by preventing its physiological functions at the cellular level. Indeed, cytokines activate signaling pathways and in turn affect EpoR-triggered signaling pathways leading to cell proliferation, differentiation, or survival [46].

It was evident that administration of Carboplatin leads to decrease in platelets and rise in leukocytes. The depletion of platelets may be due to myelosuppression or platelet aggregation. Moreover, it was demonstrated that Carboplatin induces oxidative stress injury in human thrombocytes leads to apoptosis by affecting their life span [25].The elevation of white blood cells (WBC) count might be due to infection during Carboplatin treatment or cytokines induced inflammatory reactions.

In addition, the high sensitive CRP (hsCRP), which is an acute phase protein produced by the liver and plays a role in immune response by interacting with complement. It was observed that a significant increase in hsCRP in Carboplatin groups (II \& III) could be explained by stimulation of its synthesis in response to pro- inflammatory cytokines, most notably IL-1, IL-6, and TNF- $\alpha$ [47]. C-reactive protein (hsCRP) generally has marked pro-inflammatory properties by promoting the migration of leukocytes to areas of inflammation through interaction with receptors of the Fc $\gamma$ family [47] and activates endothelial cells via interaction with lipid in cell membranes increasing activity of nitric oxide synthase (NOS) and produces free radicls [48].As shown in group VII, the pretreatment of rats with NO synthase inhibitor ; $N$-nitro- $L$-arginine methyl ester $[L-$ NAME] prevented CRP-mediated $\mathrm{O}_{2}^{-}$production and decreased endothelial nitric oxide synthase activity[48].Furthermore, high plasma concentrations of C-reactive protein (CRP) have been shown to be associated with anemia and erythropoietin- hypo-responsiveness in carboplatin induced anemia(groups II,III \& V). Also, there is positive correlation between both inflammatory markers hsCRP and TNF- $\alpha$.In agreement with our results (group V), Bárány reported that hsCRP is the best parameter correlating with erythropoietin resistance [49].

Regarding the postulated pathogenesis of direct Carboplatin - induced renal epithelial injury, Clifford [50] suggested that Carboplatin caused DNA damage, lipid peroxidation, mitochondrial dysfunction, and activation of both caspases and protein kinases. It binds with DNA to form intrastrand crosslinks and adducts that cause changes in the conformation of the DNA and affect DNA replication. Furthermore, Carboplatin induced progressive glomerular and/or tubulointerstitial fibrosis, peritubular capillary damage by hypoxia and loss of nephron function by glomerular sclerosis and tubular atrophy [38]. Inflammatory oxidative stress associated 
with pathophysiological processes of renal progression could be implicated in development of renal anemia, and subsequent inadequate response to EPO [51]. Moreover, in groups II \& III, the elevations in proinflammatory cytokines [IL-1, IL6 and TNF- $\alpha$, have been demonstrated in rats with Carboplatin -induced acute renal injury [51] and associated histopathological changes which demonstrated marked pathological changes in the form of patches of necrosis with widening of the Bowman's spaces and vaccuolation of the cytoplasm of the renal tubules and no areas of focal necrosis but Bowmans spaces still showing apparent widening with less marked signs of degeneration in the renal tubular cell lining. Also, serum cytokines may increase in carboplatin induced renal injury through many mechanisms including increased renal production, increased extra-renal production and impaired renal clearance. In addition to increase cytokines, elevation of MDA and decrease in SOD, CAT and GSH-Px levels can destroy the lipid components on cytoplasmic membrane, denature of proteins and nucleic acids resulting renal injury [52].

Hematotoxicity is more severe in particular with the larger dose $250 \mathrm{mg} / \mathrm{kg}$ and in rats with impaired kidney functions which apparent in groups III \& V by elevation of important markers of the function of the kidneys; serum creatinine ( $\mathrm{SCr}$ ), blood urea nitrogen (BUN) and marked anaemia [53]. These biochemical changes are assured by hitopathological findings as mentioned before and widened tubular lumens with vacculation of the cellular lining. In contrast, the carboplatin-induced renal injury to some extent was insignificant at dose $100 \mathrm{mg} / \mathrm{kg}$ as shown in group II, the lesions were insignificantly severe enough to reduce renal function as measured by SCr \& BUN. Also, these changes were supported by our renal histopathological changes as mentioned before. Furthermore, EPO level was significantly lower in treated rats with Carboplatin (Groups II \& III) which can be explained by nephrotoxic effect of Carboplatin [53] which confirmed in our study by results of histopathology.

Recombinant human EPO (rHuEPO) is one of the drugs used to treat chemotherapyinduced anemia. In the present study, administration of EPO in group IV decreased the level of MDA, a marker of lipid per oxidation and increased the activity of antioxidant enzymes, including SOD, CAT and GSH-Px in the serum, compared with the Carboplatin group II. EPO may exert its anti-oxidative effects directly by increasing hemoglobin oxidase-1 activity [13] and indirectly by inhibiting the activity of induced nitric oxide synthase and by turn decreasing nitric oxide (NOx) [54] as evident in group IV increasing significantly the RBCs, $\mathrm{HB}$ and PCV to reduce cellular oxidative response, since RBCs are loaded with anti-oxidative enzymes [11].

In group $\mathrm{V}$, a persistence of anemia even after the administration of exogenous EPO although a significant increase level of EPO is an index for development of resistance to EPO [55]. The mechanism of this effect needs to be fully elucidated. Resistance to EPO with impaired kidney functions clearly has the potential to increase mortality as shown in group V. Several factors have been recognized as causing resistance to EPO, notably oxidative stress and inflammation 
producing suppressive cytokines of early erythroid progenitor proliferation. In addition, proinflammatory cytokines stimulate hepcidin synthesis thus reducing iron availability for late erythropoiesis as mentioned before [44]. This also can be attributed to the development of anti-EPO antibodies (anti-EPO AAbs) which can neutralize the protein and stop RBC production in the bone marrow and is characterized by EPO resistance [56] and a decrease in hemoglobin concentration due to the decrease $\mathrm{RBC}$ production and the hemoglobin concentration drops as shown in our results in group $\mathrm{V}$.

Van et al. proved that EPO resistance could be caused by use of derivatives of chemotherabeutic platinum agents [55] which be attributed to carboplatin- induced impaired renal functions.Furthermore Carboplatin can enhance activation of T-helper type 1 (Th1) lymphocytes and monocytes secreting pro-inflammatory cytokines IL-1, IL-6 and TNF- $\alpha$, that exert proapoptotic activity to suppress erythrocyte stem cell proliferation [56] which antagonizes the antiapoptotic effect of EPO on erythroid progenitor cells.

However, Vitamin $\mathrm{C}$ is a potent watersoluble antioxidant that acts as reactive oxidants scavenger and can also regenerate the important cellular and membrane antioxidants SOD, CAT and GSH-Px [17].

In our study, the release of proinflammatory cytokines such as IL- 6 and TNF- $\alpha$ in carboplatin -induced injury could be prevented by vitamin $\mathrm{C}$ as demonstrated in group VI .On the other hand vitamin $\mathrm{C}$ not affect IL-1 production significantly. These results were in agreement with Molina et al. [57].
Furthermore, the present study revealed the association between administration of the vitamin $\mathrm{C}$ with a significant improvement in hematological parameters and EPO resistance (group VI) and recovery of renal injury in the form of almost normal renal corpuscles but still the renal tubules had wider lumens. These effects suggest a new strategy to be considering that vitamin $\mathrm{C}$ as a co-factor in treatment of Carboplatin - induced hematological disorders.

In this issue, numerous suggested mechanisms of vitamin $\mathrm{C}$ have to be considered. Vitamin C may regulate the immune-inflammatory response by its antioxidant properties [17] and acting on intracellular p38 mitogen activated protein kinase (MAPK) [58]. Moreover, vitamin C decreased lipopolysaccharide (LPS)-induced generation of the pro-inflammatory cytokines TNF- $\alpha$ and increased anti-inflammatory IL-10 production, while having no effect on IL-1 levels [57]. Also, it has been shown that vitamin C inhibit granulocyte-macrophage-colony-stimulating factor (GM-CSF)-, IL-3- and IL-5-induced signal transduction pathways [57]. Vitamin C could modulate the immune system by inhibiting $\mathrm{T}$ cell and monocytes apoptosis signaling pathways and by turn inhibit production of inflammatory mediators and modulate cytokine levels(IL-6 and TNF- $\alpha$ ) in Carboplatin -induced toxicity [59]. In addition, it was also reported that vitamin $\mathrm{C}$ caused a significantly decrease mRNA levels of IL-6 and TNF- $\alpha$ produced by liver in the stressed rats besides its antioxidant property [57].These postulations can explain the decrease of IL-6 and $\mathrm{TNF} \alpha$ production by vitamin $\mathrm{C}$ in our experimental study (group VI). The decreased vitamin $\mathrm{C}$ significantly in Carboplatin-induced 
injury as shown in groups III \& V suggesting an increased its consumption as antioxidants. In addition, vitamin $\mathrm{C}$ has anti-inflammatory properties evident by decrease endothelial cell adhesion molecule ICAM-1 expression in response to TNF-alpha and suppresses systemic neutrophil migration during inflammation [60].

In this study, MDA, NOx , cytokines (ILI,IL-6, TNF- $\alpha$ ) and hsCRP was higher in carboplatin groups (II,III \&V) and was significantly reduced in the L-NAME group VII as shown in tables $2 \& 3$. These findings were in agreement with that reported by Ishii et al., who stated that the effect of increased NOx and associated larger quantities of ROS [26].

Nitric oxide (NOx) generated by NOx synthase (NOS) enzymes [26] during inflammatory conditions has properties that allow it to be easily soluble and diffuse across biological membranes to control intracellular processes[61] .This intercellular signaling molecule is important for the immune system, as well as generating free oxygen radicals called peroxynitrites $\left(\mathrm{ONOO}^{-}\right)$, as a result of combination of NOx with superoxide, tissue damage [62] as evident in our histopathological findings or may be transformed into the more stable hydrogen peroxide radical [62]. Furthermore, NOx itself is considered as a free radical gas and plays an important role in carboplatin - induced oxidative stress was demonstrated in table 3 and groups II \& III. Nitric oxide, rather than its oxidative effect, plays a major role in occurrence of apoptosis [63] and has proinflammatory effects by increasing cytokine expression raising the concept that inhibition of NO pathways is mostly fruitful in the treatment of inflammation [64]. A positive correlation between
NOx production and increased pro-inflammatory cytokine levels (IL-1 \& IL-6\& TNF- $\alpha$ ) were reported in Carboplatin treated rats [65] and demonstrated in present study in groups II\& III. Nitric oxide production can be controlled via positive feedback loop which uses the increase in cAMP levels to activate the production of NOS and subsequent increase in NOx production which stimulate the production of IL- 6 \& TNF- $\alpha$ by both macrophages and neutrophils [66]. The release of such cytokines can stimulate NOS, leading to further NOx production and increased phagocytosis [66].

The hematological effect of NOx as evident in groups II\&III can be explained by reaction of NOx with deoxyhemoglobin produces nitrosylhemoglobin ( $\mathrm{HbFe}-\mathrm{NO})$, while that with oxyhemoglobin produced methemoglobin and nitrate. Nitrite can also react with deoxyhemoglobin to produce NOx and these reaction may be important in the pathophysiology of anemia .Also, NOx acts as a positive feedback molecule when released by tissue macrophages during phagocytosis, leading to the recruitment of further phagocytes and tissue destruction[ 6].

Also, nephrotoxic effect of proinflammatory cytokines (IL-1 and TNF $\alpha$ ), as a result of carboplatin, as demonstrated in groups II\&III, has been suggested through increased NOx via induction of NOS in proximal tubular cell [64].

Briefly, in the present study NOx level was reduced in EPO, vitamin C and L-NAME groups (III, VI \& VII) in comparison to their respective control and groups II, III and V. Moreover, the increase in blood oxidants and cytokines concentration activates high expression of NOS. This is followed by the increased production of 
NOx, which influences several signal pathways [65] and consequent Carboplatin induced complications [36]. Nevertheless, in groups II, III $\& \mathrm{~V}$, there was a close relation between oxidative stress and NOx level, as denoted by an increase in MDA and NOx [6].This effect was reversed by vitamin $\mathrm{C}$ and a non-selective NOS inhibitor (LNAME) in groups VI \& VII animals respectively, which showed reduced oxidative stress and NOx and reverse the renal insult. The almost normal renal corpuscles but still the renal tubules had wider lumens and a very close picture of normality in both the renal corpuscles and tubules were important indicators for improvement of renal morphology

Study by Schwedler et al. [26] also clarified a relationship between NOx production and CRP. In addition, the CRP has been shown to enhance NOx production in isolated human neutrophils via increased NOS activity [67]. Consequently, this study assessed the association between CRP and NOx production in groups II, III, IV and V. This in agreement with studies showing CRP can induce NOx production by neutrophils in both the presence and absence of infection [67].

Furthermore, it was manifest in group VII

that L-NAME exhibit beneficial effects on hematopoietic system by increasing RBCs, $\mathrm{Hb} \%$, PCV and platelet count against Carboplatin induced hematotoxicity markers. Elevation of erythrocyte count by L-NAME might be related to either stimulation of erythropoiesis or prevention of bone marrow suppression or the ability of LNAME as a free radical scavenging action that reduces leakage of enzymes into blood stream and stabilizes membrane permeability [68]. In addition,
L-NAME administration had significant antioxidant effects by a decline in MDA and elevation in SOD, CAT and GSH-Px in Carboplatin -treated rats (group VII). The results of our study were in agreement with previous studies [68] which had proved that L-NAME demonstrated antioxidant action on cerebral tissues, liver, and jejunum but, our data were in contrarily with the results by Selamoglu et al. [69] who showed that L-NAME in the liver may enhance oxidative stress via inhibited nitric oxide synthase.

The anticytokines effects of L-NAME were manifest in group VII which showed a specific significant decrease in IL-1 rather than other plasma inflammatory markers. Nevertheless, variations in the results in vitamin $\mathrm{C}$ and L-NAME groups did not demonstrate a significant difference, which may be due to their similar antioxidant and anti-inflammatory properties.

\section{Conclusion}

Carboplatin as a platinum compound and antineoplastic agent had a hematological toxicity and oxidant stress effect in addition to increase proinflammatory cytokines and consequent renal insult. The development of EPO resistance and histopathological changes, during treatment of Carboplatin-induced anemia, was Carboplatin dose dependent. Vitamin C and L-NAME could alleviate and counterbalance the hematological toxicity, oxidative stress, EPO resistance and decrease proinflammatory cytokines and in turn recovery of renal structure and functions. More investigations will be needed to clarify and elucidate the mechanisms of vitamin $\mathrm{C}$ and $\mathrm{L}$ NAME involved in oxidative stress \& cytokines - 
mediated anemia as a result of Carboplatin treatment.

\section{Conflicts of interest}

No conflicts of interest.

References

1. Horie S, Oya M, Nangaku M, Yasuda $Y$, Komatsu,Motoko Y Y, Kitagawa Y, Kuwano H, Nishiyama H, Ishioka C, Takaishi H, Shimodaira H, Mogi A, Ando Y, Matsumoto K, Kadowaki D,and Muto S:Guidelines for treatment of renal injury during cancer chemotherapy. Clin Exp Nephrol ; 22(1): 210-244,2018.

2. Cheng Y, Wu R, Cheng M, Du J, Hu X, Yu L, Zhao X, Yao Y, Long Q, Zhu L, Zhu J, Huang N, Liu H, Hu Y, and Wan F :Carboplatin-induced hematotoxicity among patients with non-small cell lung cancer: Analysis on clinical adverse events and druggene interactions. Oncotarget.; 8(19): 3222832236,2017 May 9.

3. Weiming XU, Liu LZ, Loizidou M, Ahmed M, Charles IG :The role of nitric oxide in cancer. Cell Res 12(5):311-20,2002.

4. Vendrel I, Macedo D, Alho I, Dionísio M. $\mathbf{R}$, Costa $\mathbf{L}$ :Treatment of Cancer Pain by Targeting Cytokines Mediators of Inflammation Volume 2015, Article ID $984570,11,2015$.

5. Corzo CA, Cotter MJ, Cheng P, Cheng F, Kusmartsev S, Sotomayor E, Padhya T, McCaffrey TV, McCaffrey JC, Gabrilovich DI :Mechanism regulating reactive oxygen species in tumor-induced myeloid-derived suppressor cells. J Immunol. 182: 5693-5701. 10.4049/jimmunol.0900092,2009.

6. García-Ortiz A, Serrador JM :Nitric oxide signaling in $\mathrm{T}$ cell-mediated immunity. Trends Mol Med 24(4):412-27. doi:10.1016/j.molmed.2018.02.002,2018.

7. Lackie J: Jump up in "Cytokine".A Dictionary of Biomedicine. Oxford UniversityPress.ISBN 9780199549351,2010.

8. Debeljak N, Solar P, Sytkowski AJ :Erythropoietin and Cancer: The Unintended Consequences of Anemia Correction. Front Immunol.; 5: 563,2014Nov 11.

9. Marsik C, Kazemi-Shirazi L, Schickbauer T :C - reactive protein and All-Cause Mortality in a Large Hospital-Based Cohort. Clin Chem. 54: 343-349. 10.1373/clinchem.2007.091959,2008.

10. Lamon S, Zacharewicz E, Stephens AN, Russell AP :EPO-receptor is present in mouse $\mathrm{C} 2 \mathrm{C} 12$ and human primary skeletal muscle cells but EPO does not influence myogenesis. Physiol Rep. 2:e00256,2014.

11. Dimitrijevic ZM, Cvetkovic TP, Djordjevic VM, Pavlovic DD, Stefanovic NZ, Stojanovic IR, Paunovic GJ and VelickovicRadovanovic RM :How the duration period of erythropoietin treatment influences the oxidative status of hemodialysis patients. Int $\mathbf{J}$ Med Sci. 9:808-815,2012.

12. Chen S, Li J, Peng H, Zhou J and Fang $H$ :Administration of erythropoietin exerts protective effects against glucocorticoidinduced osteonecrosis of the femoral head in rats. Int J Mol Med. 33:840-848.April 25, 2018. 
13. Yu T, Li L, Bi Y, Liu Z, Liu H and Li Z :Erythropoietin attenuates oxidative stress and apoptosis in Schwann cells isolated from streptozotocin-induced diabetic rats. J Pharm Pharmacol. 66:1150-1160,2014.

14. Leyland-Jones B :Breast cancer trial with erythropoietin terminated unexpectedly," Lancet Oncology, vol. 4, no. 8, pp. 459-460,2003 .

15. Teodoro M, Sandra A, Vilaça S, Carvalho MJ, Fernandes P A, Maria L, Dusse S, Gomes KB:Resistance of dialyzed patients to erythropoietin Rev Bras Hematol Hemoter. ; 37(3): 190-197,2015 May-Jun.

16. Teucher B, Olivares M, Cori H:Enhancers of iron absorption: ascorbic acid and other organic acids.Int J Vitam Nutr Res. ;74(6):403-19,2004 Nov.

17. Pehlivan FE: Vitamin C: An Antioxidant AgentNovember 4th 2016Reviewed: May 9th 2017Published: August 2nd 2017,2017 May.

18. Pickworth $\mathbf{C}$ : Vitamin $\mathrm{C}$ as a treatment for cancer: the evidence so far. Cancer Cell. April $25,2018$.

19. Vassilakopoulos T, Karatza MH, Katsaounou P, Kollintza A,Zakynthinos S, Roussos C :Antioxidants attenuate the plasma cytokine response to exercise in humans. J Appl Physiol;94:1025-32,2003.

20. Calder PC, Albers R, Antoine JM :Inflammatory disease processes and interactions with nutrition. Br J Nutr. 101 (Suppl 1): S1-S45,2009.

21. Tan GY, Yang L, Fu YQ, and Feng JH, Zhang MH :Effects of different acute high ambient temperatures on function of hepatic mitochondrial respiration, antioxidative enzymes, and oxidative injury in broiler chickens. Poult Sci. ;89:115-122,2010.

22. Gołab J, Olszewska D, Mro'z P, Kozar K, Kamin'R, Jalili A, and Bisiak MJ: Erythropoietin Restores the Antitumor Effectiveness of Photodynamic Therapy in Mice with Chemotherapy induced Anemia Clinical Cancer Research 1265. Vol. 8, 1265 1270, 2002 May.

23. Elliott S, Sinclair AM :The effect of erythropoietin on normal and neoplastic cells. Biologics. 6: 163-89,2012.

24. Harris HR, Orsini N, Wolk A : Vitamin C and survival among women with breast cancer: a meta-analysis". European Journal of Cancer. 50 (7): 1223 31 , 2014 May.

25. Oria R, Sánchez L, Houston T, Hentze MW, Liew FY, Brock JH :Effect of nitric oxide on expression of transferrin receptor and ferritin and on cellular iron metabolism in K562 human erythroleukemia cells. Blood ;85:2962,1995.

26. Schwedler SB, Kuhlencordt PJ, Ponnuswamy PP, Hatiboglu G, Quaschning T, Widder J, et al: Native C-reactive protein induces endothelial dysfunction in ApoE-/mice: implications for iNOS and reactive oxygen species. Atherosclerosis 195(2):76$84,2007$.

27. Ashraf YN : Protective effect of aged garlic extract against the oxidative stress induced by cisplatin on blood cells parameters and hepatic antioxidant enzymes in rats. Toxicol Rep;1:682-91,2016.

28. Corti A., fassine G., Marcucci F., Barbanti E., and Cassani $\mathbf{G}$ :Oligomeric Tumor Necrosis Factor (slowly converts into inactive 
forms of bioactive level Quantikine, R \& D Systems Europe, Abingdon, Oxfordshire, United Kingdom) \& were assayed by enzymelinked immunosorbent assay methods.;Biochem L;284:905,1992.

29. Price AK. Trull D. Berry EG: Gorman Development and validation of a particleenhanced turbidimetric immunoassay for Creactive protein, J. Immunol. Methods 99 205211. 1987.

30. Hunt RT, Dean SP ,Wolff: Biochem J., 256, 205-212,1988.

31. ShimizuTM, Coimbra M, de Araujo LF, Menezes AC, Seguro : Nacetylcysteine attenuates the progression of chronic renal failure, Kidney Int. 68 2208-2217,2005.

32. Tsukahara H, Miura M, Tsuchida S, Hata I, Hata K, Yamamoto K, Ishii Y, Muramatsu I, Sudo M :Effect of nitric oxide synthase inhibitors on bone metabolism in growing rats. Am J Physiol 270 (Endocrinol Metab 33):E840,1996.

33. Ramos E, Kautz L, Rodriguez R, et al:Evidence for distinct pathways of hepcidin regulation by acute and chronic iron loading in mice. Hepatology ;53(4):1333-1341,2011

34. Duconge J, Miranda-Massari JR, Gonzalez MJ, Jackson JA, Warnock W, Riordan NH :Pharmacokinetics of vitamin C: insights into the oral and intravenous administration of ascorbate. P R Health Sci J. 27 (1): 7-19,2008.

35. Ear T and McDonald PP: Cytokine generation, promoter activation and oxidant-independent NF-kappaB activation in a transfectable human neutrophilic cellular model. BMC Immunol., 9: 1414,2008 .
36. Chenais, Andriollo M, Guiraud P, Belhoussine $\mathbf{R}$, Jeannesson $\mathbf{P}$ :Oxidative stress involvement in chemically induced differentiation of K562 cells," Free Radical Biology and Medicine, vol. 28, no. 1, pp. 1827,2000 .

37. Dallalio and Means RT: Effects of oxidative stress on human erythroid colony formation: modulation by $\gamma$-interferon: Journal of Laboratory and Clinical Medicine, vol. 141, no. 6 , pp. 395-400,2003.

38. Serteser M, Koken T, Kahraman A, Yilmaz K, Akbulut G, Dilek ON :Changes in hepatic TNF-alpha levels, antioxidant status, and oxidation products after renal ischemia/ reperfusion injury in mice. J Surg Res;107:234-40,2002.

39. Boxall F, Siddik E, Judson ZH, Gore IR, Wiltshaw: E Carboplatin dosage: prospective evaluation of a simple formula based on renal function. J. Clin. Oncol.. 17: 1748-1756,1989.

40. Levi JA, Aroney RS, Dalley DN :Hemolytic anaemia after cisplatin treatment. Br Med J (Clin Res Ed) 1981; 282(6281):2003-2004. doi: 10.1136/bmj.282.6281,2003.

41. Theurl I, Schroll A, Sonnweber T, Nairz M, Theurl M, Willenbacher W, Eller K, Wolf D, Seifert M, Sun CC, Babitt JL, Hong CC, Menhall T, Gearing P, Lin HY, Weiss G :Pharmacologic inhibition of hepcidin expression reverses anemia of chronic inflammation in rats. Blood. ;118:49774984,2011.

42. Silverberg DS, Wexler D, Iaina A, Schwartz D :Correction of iron deficiency in the cardiorenal syndrome. Int $\mathrm{J}$ Nephrol; 2011:365301. PMID: 21603160,2011. 
43. Gardenghi S, Ramos P, Marongiu MF, Melchiori L, Breda L, Guy E, Muirhead K, Rao N, Roy CN, Andrews NC, Nemeth E, Follenzi A, An X, Mohandas N, Ginzburg Y, Rachmilewitz EA, Giardina PJ, Grady RW, Rivella $\mathbf{S}$ :Hepcidin as a therapeutic tool to limit iron overload and improve anemia in beta-thalassemic mice. J Clin Invest. ;120:4466-4477,2010.

44. Jordan JB, Poppe L, Haniu M, Arvedson T, Syed R, Li V, Kohno H, Kim H, Schnier PD, Harvey TS, Miranda LP, Cheetham J, Sasu BJ :Hepcidin revisited, disulfide connectivity, dynamics, and structure. J Biol Chem. ;284:24155-24167,2009.

45. Cooper AC, Mikhail A, Lethbridge MW, Kemeny DM, Macdougall IC: Increased expression of erythropoiesis inhibiting cytokines (IFN-gamma, TNF-alpha, IL-10, and IL-13) by $\mathrm{T}$ cells in patients exhibiting a poor response to erythropoietin therapy. J Am Soc Nephrol;14:1776-84,2003.

46. Buck F, Morceau S, Cristofanon S, Reuter, Dicato M, Diederich $\mathbf{M}$ :The inhibitory effect of the proinflammatory cytokine TNF $\alpha$ on erythroid differentiation involves erythroid transcription factor modulation. International Journal of Oncology, vol. 34, no. 3, pp. 853-860,2009

47. Black S, Kushner I, Samols D :C-reactive protein. J Biol Chem 279(47):48487-90,2004.

48. Ji SR, Ma L, Bai CJ, Shi JM, Li HY, Potempa LA, et al. :Monomeric C-reactive protein activates endothelial cells via interaction with lipid raft microdomains. FASEB J 23(6):1806-16, 2009.
49. Bárány $\mathbf{P}$ :Inflammation, serum C-reactive protein, and erythropoietin resistance Nephrology Dialysis Transplantation, Volume 16, Issue 2, 1, Pages 22427, https://doi.org/10.1093/ndt/16.2.224, 2001 February.

50. Clifford W $\quad$ F $\quad$ :Platinum based radiochemotherapies: free radical mechanisms and radiotherapy sensitizers.Free Radical Biology and Medicine 99 ,99-109, 2016.

51. Perez-Cruz I, Carcamo JM, Golde DW :Vitamin C inhibits FAS induced apoptosis in monocytes and U937 cells. Blood;102:33643,2003.

52. Tohamy AA, Ahmed MA, Ahmed EA, Romissaa HS :Cinnamic acid attenuates cisplatin-induced hepatotoxicity and nephrotoxicity. J Basic Environ Sci;3:19,2016.

53. Jaime $\mathbf{R}$ Merchan, Kenar D Jhaveri :Chemotherapy nephrotoxicity and dose modification in patients with renal insufficiency: Conventional cytotoxic agents, 2018.

54. Yang FL, Subeq YM, Chiu YH, Lee R P, Lee CJ and Hsu BG : Recombinant human erythropoietin reduces rhabdomyolysisinduced acute renal failure in rats. Injury. 43:367-373,2012.

55. Putten KV, Braam B, Jie KE, Gaillard CA .Mechanisms of Disease: erythropoietin resistance in patients with both heart and kidney failure. Nat Clin Pract Nephrol. 2008 Jan;4(1):47-57. 2008 Jan.

56. Macdougall IC, Copper AC :Erythropoietin resistance: the role of inflammation and 
proinflammatory cytokines. Nephrol Dial Transplant ;17:39-43,2002.

57. Molina N, Morandi, Bolin AC, Otton AP: Comparative effect of fucoxanthin and vitamin $\mathrm{C}$ on oxidative and functional parameters of human lymphocytes. Int. Immunopharmacol. 22, 41-50,2014.

58. Ferron-Celma I, Mansilla A,Hassan L, Garcia-NavarroA, CominoAM, Bueno $P$, Ferron JA :Effect of vitamin $\mathrm{C}$ administration on neutrophil apoptosis in septic patients after abdominal surgery. J. Surg. Res. 153, 224230,2009 .

59. Mikirova N, Riordan $\mathbf{N}$, Casciari $\mathbf{J}$ :Modulation of Cytokines in Cancer Patients by Intravenous Ascorbate Therapy. Med. Sci. Monit. 22, 14-25,2016.

60. Vassilakopoulos T, Karatza MH, Katsaounou P, Kollintza A,Zakynthinos S, Roussos C :Antioxidants attenuate the plasma cytokine response to exercise in humans. $\mathrm{J}$ Appl Physiol;94:1025-32,2003.

61. Sharma JN, Al-Omran A, Parvathy SS .Role of nitric oxide in inflammatory diseases: Inflammopharmacology 15(6):2529,2007 .

62. Tripathi P, Kashyap L, Singh V:The role of nitric oxide in inflammatory reactions, FEMS Immunology \& Medical Microbiology, Volume 51, Issue 3, Pages 443-452, December 2007.

63. Rawlingson $\mathbf{A}$ : Nitric oxide, inflammation and acute burn injury. Burns 29(7):631-40, 2003.

64. Lo Faro ML, Fox B, Whatmore JL, Winyard PG, Whiteman M .Hydrogen sulphide and nitric oxide interactions in inflammation. Nitric Oxide 41:38-47. doi:10.1016/j.niox.2014.05.014,2014.

65. Soufli I, Toumi R, Rafa H, Touil-Boukoffa C :Overview of cytokines and nitric oxide involvement in immuno-pathogenesis of inflammatory bowel diseases World $\mathrm{J}$ Gastrointest Pharmacol Ther. 6; 7(3):353-60, 2016 Aug .

66. Tumer C, Bilgin HM, Obay BD, Diken H, Atmaca M, Kelle $\mathbf{M}$ :Effect of nitric oxide in phagocytic activity of ipopolysaccharideinduced macrophages: possible role of exogenous L-arginine. Cell Biol Int 31(6):565-9,2007.

67. Khreiss T, József L, Potempa LA, Filep JG :Loss of pentameric symmetry in C-reactive protein induces interleukin- 8 secretion through peroxynitrite signaling in human neutrophils. CircRes 97(7):6907,2005.

68. Ayhancı A, Appak S, Cengiz M :1-NAME as a Synthetic Antioxidant in Liver Injuries. Oxidative Stress and Dietary Antioxidants, Pages 131-137,2018

69. Selamoglu ZS, Ozdemir I, Ciftci O, Gulhan MF, Savci A :Antioxidant Effect of Ethanolic Extract of Propolis in Liver of L-NAME Treated Rats. Adv Clin Exp Med. 24(2):22732, 2015 Mar-Apr . 